\title{
The Future of Precarious Status Migrants' Right to Health CARE IN CANAda
}

\author{
Y.Y. BRANDON CHEN ${ }^{*}$
}

This article examines how health care services in Canada are denied to precarious status migrants, either through outright exclusion based on immigration status, or due to the realities in migrants' lives that make it difficult for them to access health care services. The author argues that this situation is unfair, given the contribution made by precarious status migrants to Canada's sociocultural and economic fabric, and exhorts the courts and policymakers to do more to make health care services available to these migrants.

\section{TABLE OF CONTENTS}

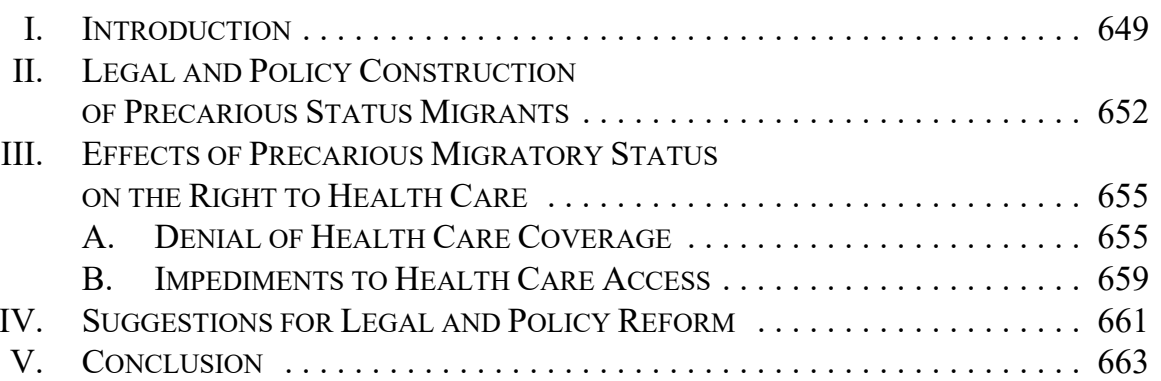

\section{INTRODUCTION}

With perhaps the exception of the staunchest supporters of libertarianism, it is generally agreed today that governments ought to play a role in facilitating the pursuit of health care for all. ${ }^{1}$ In Canada, this public responsibility was acknowledged as early as half a century ago by then federal health minister A.J. MacEachen, who described the government's push for a universal medical care system as grounded in a "fundamental principle that health is not a privilege tied to the state of one's bank account, but rather a basic right which should be open to all."' Such commitment to universal health care, depending on one's philosophical bent, has been hailed as a critical step toward the achievement of either equality of opportunity or equal human capability, as well as an important mechanism that fosters and strengthens the bonds between members of a community. ${ }^{3}$

In this article, I adopt the view from the outset that the normative underpinnings of universal health care apply equally to citizens and foreign residents in a given society. This stance echoes that of Norman Daniels and Keren Ladin. They, writing in the context of

Assistant Professor, Faculty of Law, Common Law Section, University of Ottawa. A lawyer and social worker by training, his scholarly interests lie at the intersection of health care and international migration.

But see Paul Menzel \& Donald W Light, "A Conservative Case for Universal Access to Health Care" (2006) 36:4 Hastings Center Report 36.

House of Commons Debates, 72nd Parl, 1st Sess, Vol 7 (12 July 1966) at 7545.

See e.g. Norman Daniels, "Justice, Health, and Healthcare" (2001) 1:2 American J Bioethics 2 at 3-6; JP Ruger, "The Moral Foundation of Health Insurance" (2007) 100:1 QJM 53; "Universal Access to Health Care" (1995) 108:6 Harv L Rev 1323. 
undocumented migration in the United States, argue that migrants should constitute cooperating members of the receiving society insofar as they contribute to its economy and social fabric. And to ensure the fairness of their social cooperation, migrants' equality of opportunity must be safeguarded in part by their being extended health care coverage. ${ }^{4}$ Michael Walzer has arrived at a similar position from a communitarian line of thought. Relying on guest workers in Europe as his point of reference, he insists that migrants who "do socially necessary work, and ... are deeply enmeshed in the legal system of the country to which they have come" must be accepted as members of said political community. This membership bestowed on migrants both the responsibility and the right to partake in the collective provision of security and welfare such as health care, and this arrangement of mutual aid in turn reinforces the special links between migrants and their fellow community members. ${ }^{6}$

Prevailing international human rights norms also stipulate for the equal incorporation of citizens and migrants in governmental actions that aim at achieving health care for all. Foremost, the International Covenant on Economic, Social and Cultural Rights guarantees "the right of everyone to the enjoyment of the highest attainable standard of physical and mental health,"7 and prohibits discriminatory enforcement thereof. ${ }^{8}$ This right has been interpreted as encompassing a right to timely and appropriate health care, which requires governments to, among other things, refrain "from denying or limiting equal access for all persons, including ... asylum-seekers and illegal immigrants, to preventive, curative and palliative health services." Such a principle of non-discrimination has been reiterated by multiple international human rights actors. For example, the United Nations Special Rapporteur on the right to health notes in his report concerning migrant workers that, as a part of their legal obligations, governments of receiving countries must "ensure availability and accessibility of quality health facilities, goods and services, including existing health insurance schemes, to migrant workers, on the basis of equality with other nationals." 10 Likewise, the UN Committee on the Elimination of Discrimination Against Women has called on receiving states to "take all appropriate measures to ensure non-discrimination and the equal rights of women migrant workers," 11 including securing their access to linguistically and culturally appropriate, gender sensitive health services. ${ }^{12}$

When compared with these international standards, the degree of health care protection enjoyed by migrants in Canada often falls short. This unfortunate fact will serve as my starting point in this essay as I seek to appraise the future prospects of migrants' continued

Norman Daniels \& Keren Ladin, "Immigration and Access to Health Care" in John D Arras, Elizabeth Fenton \& Rebecca Kukla, eds, The Routledge Companion to Bioethics (New York: Routledge, 2015) 56.

Michael Walzer, Spheres of Justice: A Defense of Pluralism and Equality (New York: Basic Books, $1983)$ at 60.

Ibid at 64-65.

16 December 1966, 993 UNTS 3, art 12(1) (entered into force 3 January 1976).

Ibid, art 2(2).

General Comment No. 14: The Right to the Highest Attainable Standard of Health, UNESCROR, 22nd Sess, UN Doc E/C.12/2000/4 (2000) at para 34.

10 Anand Grover, Report of the Special Rapporteur on the Right of Everyone to the Enjoyment of the Highest Attainable Standard of Physical and Mental Health, UNHRCOR, 23d Sess, UN Doc. $\mathrm{A} / \mathrm{HRC} / 23 / 41$ (2013) at para 11.

11 General Recommendation No. 26 on Women Migrant Workers, UNCEDAWOR, 42nd Sess, UN Doc CEDAW/C/2009/WP.1/R (2008) at para 26.

Ibid at para 26(i). 
struggle to realize their right to health care in this country. More precisely, my attention will be directed to the legal and policy realities facing migrants with precarious immigration status in Canada as they encounter some of the greatest disadvantages when accessing health care. Among these migrants are temporary foreign workers, international students, undocumented migrants, and relatives of Canadians that are on visitor visas while awaiting sponsorship. My central thesis is that, over the last several decades, Canadian laws and public policies on immigration and health care have coalesced to manufacture a migrant underclass who, because of their temporarized or illegalized presence in the country, are either rendered undeserving of public health care coverage or deprived of any meaningful access to the health care that they are entitled to on paper. It follows that, to actualize these migrants' right to health care, the machinations of Canada's contemporary immigration system that condemn migrants to a state of perpetual precariousness must be exposed and rejected by decision-makers.

To make my case, I will first untangle the web of immigration laws and policies in Canada that have precipitated, often in a racialized and gendered fashion, the precarious presence of a rising number of migrants. Then, I will take stock of how these migrants' precarious legal status has impaired their health care entitlement and access. I will conclude by looking ahead and offering some suggestions for legal and policy reform with an eye to promote better alignment between migrants' right to health care in Canada and international human rights law.

Before proceeding, I must make one caveat regarding the scope of this article. While cognizant of the precariousness that typifies refugee claimants' lives in Canada, ${ }^{13}$ my discussions here will mostly skirt migrants who are in, or have gone through, the asylum seeking process. This decision is primarily motivated by the fact that refugee claimants' health care in Canada is administered by a program separate from the general public health insurance scheme, and therefore warrants its own analysis that I unfortunately cannot do justice to within the confines of this article. All I wish to note on the subject is that, after experiencing significant cuts in 2012, public health care coverage for refugee claimants in Canada was restored in April 2016 to a level on par with citizens' entitlement, owing largely to the well-coordinated and determined advocacy led by health care professionals which included a successful constitutional challenge. ${ }^{14}$ Although much work remains to ensure refugee claimants' reinstated health care entitlement actually translates into improved access on the ground, the success of this advocacy reveals what is possible when key actors work in concert and commit to advancing the agenda of health care for all.

13 See e.g. Samantha Jackson, “Citizenship Theatre’: Refugee Claimants, Security, and Performing Citizenship at the Immigration and Refugee Board” (2014) 4:4 Queen's Policy Rev 1, online: <www. queensu.ca/sps/qpr/sites/webpublish.queensu.ca.qprwww/files/files/5\%20citizenship\%20theatre.pdf $>$; Priya Kissoon, "Precarious Immigration Status and Precarious Housing Pathways: Refugee Claimant Homelessness in Toronto and Vancouver" in Luin Goldring \& Patricia Landolt, eds, Producing and Negotiating Non-Citizenship: Precarious Legal Status in Canada (Toronto: University of Toronto Press, 2013) 195.

14 Nicholas Keung, "Ottawa to Restore Refugee Benefits," Toronto Star (19 February 2016) A1, online: $<$ https:/www.thestar.com/news/immigration/2016/02/18/ottawa-to-restore-and-expand-health-care-forrefugees.html>. 


\section{Legal ANd Policy Construction of Precarious Status Migrants}

Immigration laws and policies operationalize the borders of a political community by defining who may be let in and under what conditions. This immigration control apparatus employs a constellation of oversimplified binaries - namely, citizens/aliens, legal/illegal migrants, permanent/temporary residents, and so on — to privilege certain newcomers by affording them the right to permanent residency and citizen-like entitlements, while marginalizing others by ascribing them less-than-full legal statuses that are "designed to hold people in a particular relationship of exploitation and social/political subordination in the country." ${ }^{15}$ Specifically, migrants with less-than-full statuses are not always authorized to work, their lawful presence is sometimes contingent on the ongoing sponsorship of a third party, and, they are frequently denied the socioeconomic protection offered by the state. ${ }^{16}$ In this section, I intend to make two claims. First, I suggest that in recent decades, a growing number of migrants have been admitted to Canada under entrant categories that are less secure, and this trend is expected to persist in the near future. Second, I contend that such funnelling of migrants through precarious migratory pathways is a deliberate policy choice that aims at achieving the twin objectives of maximizing the potential of migrants as flexible labourers and minimizing government's social expenditure.

Although Canada's immigration program is historically billed as one that embraces permanent settlement, of late, it has exhibited an increasing penchant for temporary migration. In the last two decades, whereas the number of individuals granted permanent residency each year rose modestly from about 213,000 to 260,000 , the amount of migrants issued temporary permits annually more than doubled, jumping from roughly 253,000 to $600,000 .{ }^{17}$ Among these temporary foreign residents, the number of those granted a student permit ballooned from approximately 31,000 per year during the early 1990 s to 96,000 twenty years later. ${ }^{18}$ The ranks of temporary foreign workers have shown a similar surge, particularly since the 2000s. Between 2006 and 2010, the number of temporary employment authorizations issued to foreign workers grew by an average of 9 percent yearly, which was almost twice the rate observed during the second half of the $1990 \mathrm{~s} .{ }^{19}$ This proliferation of short-term migrant workers is underscored by the expansion of Canada's Temporary Foreign Worker Program (TFWP) into "lower-skilled" occupations. As ever more migrant workers take up jobs as cooks, wait staff, cleaners, construction labourers, and so forth, today's TFWP is marked by a pool of predominantly racialized participants from the Global South, with an increasing proportion of females. ${ }^{20}$ While some restrictions to the TFWP were introduced in 2015 by the Canadian government to quell public outcry over the influx of Nandita Sharma, "Immigration Status and the Legalization of Inequality" in Harald Bauder \& John
Shields, eds, Immigrant Experiences in North America: Understanding Settlement and Integration (Toronto: Canadian Scholars' Press, 2015) 204 at 208.

16 Luin Goldring, Carolina Berinstein \& Judith K Bernhard, "Institutionalizing Precarious Migratory Status in Canada" (2009) 13:3 Citizenship Studies 239 at 240-41.

17 Calculation performed by author using statistics provided by "Facts and Figures 2014 - Immigration Overview: Permanent and Temporary Residents," online: <www.cic.gc.ca/english/resources/statistics/ facts2014/> ["Facts and Figures 2014"].

18 Statistics Canada, International Students Who Become Permanent Residents in Canada, by Yuqian Lu \& Feng Hou, Catalogue No 75-006-x (Ottawa: Minister of Industry, 2015) at Table 1.

"Facts and Figures 2014," supra note 17.

Jason Foster, "Making Temporary Permanent: The Silent Transformation of the Temporary Foreign Worker Program" (2012) 19 Just Labour 22 at 27-29. 
migrant workers amid rising unemployment in the country, notable exemptions have been granted to certain regions and sectors, thus ensuring temporary foreign workers will remain a fixture in Canada's immigration system for the time being. ${ }^{21}$

Undoubtedly, a good portion of the temporary migrant population consists of individuals that are truly looking to pursue time limited projects in receiving countries. However, for many others, their designation as temporary foreign residents fails to capture the nuances of their lived realities. For a growing number of foreign nationals in Canada, particularly those deemed "high-skilled," temporary migration represents only an initial stage of their yearslong path toward permanent residency. By way of example, between 2005 and 2014, the number of temporary foreign workers who transitioned to permanent residents in Canada more than quintupled, rising from 8,500 to 49,400 annually. ${ }^{22}$ A contributing factor to this boom was the launch of the Canadian Experience Class in 2008, which allows select international students who have acquired Canadian work experience upon graduation to qualify for permanent residency. ${ }^{23}$ Some of these migrant workers have the intention all along to immigrate to Canada on a permanent basis, and they see temporary migration as a steppingstone to their eventual goal as they are unable to meet the stringent immigration requirements straightaway. ${ }^{24}$ For other temporary migrants, the decision to stay is only made once they are in the country. As studies on various guest worker programs around the world show, people commonly adjust their plans when they progress through different phases of life, when they develop relationships and become integrated with local communities, or when the socioeconomic conditions change back home. ${ }^{25}$

The distinction between temporary and permanent migration can be equally blurry for many "lower-skilled" migrants with time-limited permits that lack the option of transitioning to permanent residents. For instance, three-quarters of the Mexican migrant farm labourers that work in Canada seasonally have returned on an annual basis for over four years, and 22 percent of them over ten years. ${ }^{26}$ Such extended presence, often accompanied by the development of close ties with the local population, challenges the appropriateness of classifying these migrants as temporary residents. In a similar manner, the migration of many lower-skilled, non-agricultural workers to Canada via the TFWP also used to defy the label of temporariness. For over a decade, lower-skilled migrants whose work authorizations had expired were generally able to apply for a new permit or to renew their existing permit for as many times as they desired, thus opening the door to their establishment of relatively prolonged residence in Canada. ${ }^{27}$

"More Foreign Workers Welcomed," The Chronicle Herald (18 March 2016) B4.

"Facts and Figures 2014," supra note 17.

Ana M Ferrer, Garnett Picot \& William Craig Riddell, "New Directions in Immigration Policy: Canada's Evolving Approach to the Selection of Economic Immigrants" (2014) 48:3 Intl Migration Rev 846 at 857.

Delphine Nakache \& Leanne Dixon-Perera, “Temporary or Transitional? Migrant Workers' Experience with Permanent Residence in Canada" (2015) 55 IRPP Study 1 at 12-13 [Nakache \& Dixon Perera, "Temporary or Transitional?"].

See e.g. Stephen Castles, "Guestworkers in Europe: A Resurrection?" (2006) 40:4 Intl Migration Rev 741; Siew-Ean Khoo, Graeme Hugo \& Peter McDonald, "Which Skilled Temporary Migrants Become Permanent Residents and Why?" (2008) 42:1 Intl Migration Rev 193.

Jenna Hennebry, "Permanently Temporary? Agricultural Migrant Workers and Their Integration in Canada" (2012) 26 IRPP Study at 13.

Delphine Nakache \& Paula J Kinoshita, "The Canadian Temporary Foreign Worker Program: Do ShortTerm Economic Needs Prevail Over Human Rights Concerns?" (2010) 5 IRPP Study 1 at 34. 
However, in an attempt to emphasize the supposedly temporary nature of migrants' participation in the TFWP, a policy that took effect on 1 April 2015, now bars lower-skilled foreign workers who have been in Canada for over four years from being issued a new work permit until they spend at least four years outside the country. ${ }^{28}$ It is widely believed that, of the many migrants who are caught by this rule and lack the ability to secure alternative legal statuses in Canada, a sizable segment would end up remaining in the country without permission rather than departing at the end of four years. Some of them may do so because their families back home rely on their remittances; others may be pressured to continue working in Canada in order to repay the money they owe to recruiters; still others may find it difficult to leave because they have put down roots here. ${ }^{29}$ If this forecast comes to pass, the "four-in, four-out" policy would arguably do little to prevent the long-term presence of migrant workers and would simply drive it underground.

Given the extent of the mismatch between migrants' temporary designation and their real life circumstances, the expanding pool of foreign nationals admitted to Canada with lessthan-full legal statuses is better understood as the product of a conscious policy decision. On one level, as instability associated with individuals' immigration process frequently carries over into their employment, the policy shift from permanent to temporary migration helps Canada "deliver a workforce more willing to accept the industry's working and living conditions and one less able to contest them." 30 That is, because many precarious status migrants depend on the goodwill of their employers to keep returning to, or residing in, Canada or to successfully transition into permanent residents, they are vulnerable to exploitation at work and are often unwilling or unable to seek recourse in the event of maltreatment. ${ }^{31}$ The barriers to speaking out are even greater if migrant workers are issued a "closed" work permit that largely prohibits them from switching jobs. ${ }^{32}$ Thus, by virtue of the conditionality associated with their precarious legal statuses, migrants are transformed into "flexible" workers coveted in the market economy who can be fully taken advantage of by employers when the demand for labour is high while remaining readily disposable when the demand sags.

On another level, the imposition of less-than-full legal statuses on migrants who for all intents and purposes have established protracted residence in Canada can be seen as part and parcel of the neo-liberal downward pressure on social citizenship rights. ${ }^{33}$ In other words, by casting migrants that are ordinarily present as merely visitors or guests, the government insidiously excludes them from full membership and the attendant entitlements despite their ongoing contributions to society that arguably help sustain such communal provisions. One

Nakache \& Dixon-Perera, "Temporary or Transitional?" supra note 24 at 18.

Audrey Macklin, "Manufactured Illegality,” Nationals Post (20 March 2015) A10.

Kerry Preibisch, "Pick-Your-Own Labor: Migrant Workers and Flexibility in Canadian Agriculture" (2010) 44:2 Intl Migration Rev 404 at 413 [emphasis omitted].

See e.g. Fay Faraday, Made in Canada: How the Law Constructs Migrant Workers' Insecurity (Toronto: Metcalf Foundation, 2012), online: <metcalffoundation.com/wp-content/uploads/2012/ 09/Maac-In-Canada-Full-Report.pdf>; Lilian Magalhaes, Christine Carrasco \& Denise Gastaldo, "Undocumented Migrants in Canada: A Scope Literature Review on Health, Access to Services, and Working Conditions" (2010) 12:1 J Immigrant \& Minority Health 132; Salimah Valiani, "The Shifting Landscape of Contemporary Canadian Immigration Policy: The Rise of Temporary Migration and Employer-Driven Immigration" in Goldring \& Landolt, supra note 13, 55.

Faraday, ibid at 76-77.

See generally Janine Brodie, "The Social in Social Citizenship" in Engin F Isin, ed, Recasting the Social in Citizenship (Toronto: University of Toronto Press, 2008) 20. 
of the clearest examples of this rights curtailment by way of "status temporarization" concerns elderly migrants. Traditionally, the primary method for Canadians to bring their non-citizen parents and grandparents to the country for reunification was through family sponsorship, which, if successful, affords permanent residency to these elderly newcomers. Since late 2011, the Canadian government has consciously diverted elderly migrants away from this usual route of permanent settlement to a newly created "super visa" program. The super visa, which enables holders multiple entries into Canada over a period of up to ten years and a maximum stay of twenty-four months on each visit, gives parents and grandparents of Canadians the possibility of remaining in the country on a relatively longterm basis. But it provides them neither the right of permanent residency nor any associated socioeconomic benefits, including public health care coverage. ${ }^{34}$ In effect, by fictitiously turning ordinary residents into temporary visitors, the government conveniently carves out a policy space for itself in which it enjoys enhanced freedom to offload the responsibility of health and social care onto migrants and their families.

In the upcoming section, I will pick up on this last point. In particular, I wish to elaborate on the ways that the rights reducing policy space gets generated and maintained in the domain of migrant health care, focusing especially on the role that the Canadian judiciary has played in this process.

\section{EfFects of Precarious Migratory Status ON THE Right TO HEALTH CARE}

Generally speaking, migrants who have been granted permanent residency in Canada enjoy more or less the same publicly funded health care as Canadian citizens. ${ }^{35}$ In contrast, many precarious status migrants lack either health care entitlement outright or the ability to exercise whatever right to health care they supposedly have. I will now address these two gaps in precarious status migrants' health care in turn.

\section{A. Denial of Public Health Care Coverage}

Precarious status migrants' entitlement to publicly funded health care in Canada is best described as patchy. Among temporary foreign workers, those lacking an employment authorization that is at least six months long, or a year long in some provinces, are usually disqualified from coverage. ${ }^{36}$ In Quebec, ironically, many migrants that hold an "open" work permit, which allows them to switch jobs and should in theory better protect them from exploitation, are left medically uninsured. ${ }^{37}$ As for international students, they are completely

34 Xiaobei Chen \& Sherry Xiaohan Thorpe, "Temporary Families? The Parent and Grandparent Sponsorship Program and the Neoliberal Regime of Immigration Governance in Canada" (2015) 1:1 Migration, Mobility \& Displacement 81, online: <https://journals.uvic.ca/index.php/mmd/article/ download/13308/4418>.

35 However, several provinces require new residents to undergo a waiting period before they are eligible for public health care coverage, and this policy has disproportionately adverse effects on migrants, including permanent residents. See Ritika Goel, Gary Bloch \& Paul Caulford, "Waiting for Care: Effects of Ontario's 3-Month Waiting Period for OHIP on Landed Immigrants" (2013) 59:6 Can Family Physician e269.

36 YY Brandon Chen, "Extending Health Care Entitlement to Lawful Non-Transient International Migrants: Untapped Potential of the Universality Principle in the Canada Health Act" (2015) 48:1 UBC L Rev 79 at 111-12 [Chen, "Extending Health Care Entitlement"].

37 Ibid at $113-14$. 
excluded from public health care plans in Ontario, New Brunswick, and Prince Edward Island. And most other Canadian jurisdictions restrict health care entitlement to only foreign students that meet certain criteria, including being issued a permit that is for twelve months or longer. ${ }^{38}$ Non-citizen family members of Canadians that are in the country on visitor visas while waiting for the approval of their sponsorship applications are not eligible for health care benefits, nor are parents and grandparents on super visas. ${ }^{39}$ The same is true of undocumented migrants. ${ }^{40}$ Although some provinces do provide primary health care to medically uninsured migrants through community health centres and the like, such services are far from comprehensive, and access thereto is often impeded by long waiting lists and catchment area restrictions. $^{41}$

The inequality between the health care entitlement of precarious status migrants and that of citizens and permanent residents is routinely justified by provincial governments as necessary prioritization in a context of limited public resources. As a case in point, when Ontario decided to restrict temporary migrants' access to its health insurance plan in 1994, the health minister defended the decision on the basis that the province needed "tighter controls on health care spending ... to preserve the system for Ontario residents." ${ }^{42}$ The government's stance displayed little appreciation for the contributions that precarious status migrants make to the public coffers through both direct and indirect taxations. Neither did it give proper weight to the extended presence of many precarious status migrants in the province that ought to qualify them as ordinary "residents" in virtually every sense of the word.

In an attempt to improve their health care security, precarious status migrants have repeatedly challenged their incomplete public health care coverage in court, but largely to no avail. ${ }^{43}$ Most commonly, they have framed their lesser health care entitlement relative to that of citizens and permanent residents as a contravention of the equality rights guarantee under the Canadian Charter of Rights and Freedoms. ${ }^{44}$ To date, however, courts in Canada have consistently dismissed this line of argument by finding that disparities in health care benefits arising from migratory status differences do not come within the purview of the Charter equality rights protection.

It is well-established in the Charter jurisprudence that the equality rights provision is not engaged unless a government action creates a discriminatory distinction based on one of the grounds enumerated in section 15 or one that is analogous thereto. ${ }^{45}$ But according to a

Ibid at $114-15$.

Ibid at 117 .

Magalhaes, Carrasco \& Gastaldo, supra note 31.

Sandra Elgersma, Immigration Status and Legal Entitlement to Insured Health Services, Library of Parliament PRB 08-28E (Ottawa: Parliamentary Research and Information Service, 28 October 2008) at 7.

42 Ontario, Legislative Assembly, Official Report of Debates (Hansard), 35th Leg, 3rd Sess, No 106 (31 March 1994) at 5322 (Hon Ruth Grier] [emphasis added].

43 To the best of the author's knowledge, the only court challenge in Canada that has hitherto succeeded in expanding precarious status migrants' health care entitlement is the case against the federal government's cuts to refugee health care: Canadian Doctors for Refugee Care $v$ Canada (Attorney General), 2014 FC 651, 28 Imm LR (4th) 1.

44 Part I of the Constitution Act, 1982, being Schedule B to the Canada Act 1982 (UK), 1982, c 11 [Charter].

Andrews v Law Society British Columbia, [1989] 1 SCR 143. 
growing number of courts that have examined this issue, unequal health care entitlements between precarious status migrants and their more privileged counterparts rests on neither an enumerated nor an analogous ground. In reaching this conclusion, courts have often relied on unrealistic assumptions about how precarious status migrants came to their predicament and what they can do to escape it. For example, in Clarken et al. v. Ontario Health Insurance Plan, Ontario's Divisional Court dismissed a section 15 Charter challenge launched by a group of foreign students whose entitlement to provincial health insurance was stripped following the above-mentioned policy change in $1994 .{ }^{46}$ The Court ruled against recognizing immigration status as an analogous ground for Charter equality rights protection because it apparently lacked the requisite immutability. Justice Chilcott noted that international students were not prohibited from qualifying for public health care coverage per se, and all they had to do to become eligible was to acquire another immigration status. ${ }^{47}$ The Court was technically correct in its observation. However, the degree of liberty that it assumed foreign students to boast when it came to changing their legal classification to one that was more permanent and embellished with greater entitlements was troublingly fanciful, especially considering that the case predated the introduction of the Canadian Experience Class. Scant attention was paid by the Court to the systemic forces within the Canadian immigration system mentioned earlier that were beginning, and have continued to this day, to narrow migrants' lawful access to permanent settlement in favour of temporary entry. Given the substantial political advantage that the government stands to gain by keeping migrants in a state of precariousness, suggestions that migrants can freely improve their health care situations by adopting a securer migratory status are arguably unreasonable.

Similar shortcomings also afflict the Ontario Court of Appeal decision in Irshad (Litigation guardian of) $v$. Ontario (Ministry of Health), which concerned another unsuccessful section 15 Charter challenge against the same benefit-cutting policy examined in Clarken. ${ }^{48}$ The claimants in this case consisted of precarious status migrants whose legal standing in Canada ranged from having no status at all to being medically inadmissible dependent children of landed immigrants who were allowed entry on special permits. As in Clarken, the Court found that immigration status, particularly the distinction between permanent and non-permanent residents, could not constitute an analogous ground under section 15 because it was not immutable. As support for its ruling, the Court noted that four of the five applicants in this case transitioned into permanent residents in the course of the litigation, while options existed for the fifth to do the same in theory. ${ }^{49}$ Effectively, by restricting its field of vision to the handful of claimants in this case, the Court cast out of sight many other precarious status migrants in Canada, particularly those labelled "lowerskilled," for whom the likelihood of acquiring permanent resident status is practically nonexistent by policy design. ${ }^{50}$ Compounding the problem, the Court went on to observe that immigration status, instead of constituting a suspicious ground of discrimination, was in fact a relevant policy consideration in this case given the government's desire to limit health care

(1998), 109 OAC 363 [Clarken].

Ibid at para 50.

(2001), 55 OR (3d) 43 (CA) [Irshad].

Ibid at para 136.

Deepa Rajkumar et al, “At the Temporary-Permanent Divide: How Canada Produces Temporariness and Makes Citizens Through its Security, Work, and Settlement Policies" (2012) 16:3 \& 4 Citizenship Studies 483 at 486 . 
coverage to only those who intended to make Ontario their permanent home. ${ }^{51}$ The upshot of the Court's holding was that migrants' legal characterization as either permanent or nonpermanent was an adequate proxy for the true nature of their residence in the province. But as I explained earlier, this is far from the reality. Despite the temporariness and conditionality associated with their legal status, many precarious status migrants not only intend to remain in Canada on a long-term basis but also do so as a matter of fact owing to their tremendous resilience. To discount migrants' ordinary residency solely because of their non-permanent legal designation therefore belies people's real life experiences.

The blindness of the Canadian judiciary to the plight of precarious status migrants and the purposive policy design that fuels such hardship reared its head again in Toussaint $v$. Canada (Attorney General), in which the Federal Court of Appeal was tasked with determining the constitutionality of the federal government's denial of public health care benefits to an undocumented migrant woman. ${ }^{52}$ In disposing of the applicant's Charter equality rights claim, the Court cited Irshad as authority and affirmed that immigration status did not meet the requirements of an analogous ground as it could not be characterized as "immutable or changeable only at unacceptable cost to personal identity." ${ }^{, 53}$ This finding painted an overly rosy picture of undocumented migrants' legal quandary by implying that they were free to regularize their presence in the country without incurring much personal sacrifice. It trivialized the real possibility of deportation that undocumented migrants would face when presenting themselves to government officials. And to the extent that their lives had become intertwined with the sociocultural and economic fabric of the Canadian society, attempts by undocumented migrants to re-engage with the immigration system to change their legal status would run great risk of their losing these social attachments, and could hardly be said to cause no "unacceptable cost to personal identity." 54

Notably, in Toussaint, the Court was also called upon to decide whether the exclusion of undocumented migrants from public health care violated the applicant's rights to life and personal security as enshrined in section 7 of the Charter. Once more, the Court was unsympathetic toward the applicant's claim, and its analysis exhibited stubborn ignorance of the systemic forces that shape and perpetuate precarious status migrants' realities. According to the Court, section 7 Charter protection was not triggered in this case because the government could not be held responsible for the harm suffered by the applicant. It reasoned that "the [applicant] by her own conduct ... [had] endangered her life and health. [She] entered Canada as a visitor. She remained in Canada for many years, illegally. Had she acted legally and obtained legal immigration status in Canada, she would have been entitled to coverage under the [provincial health insurance plan]. ${ }^{, 55}$ There was no acknowledgment by the Court of the increasing reliance of the Canadian immigration regime on temporary migration, which aggravated migrants' vulnerability to falling out of status, as expected in the aftermath of the coming into effect of the "four-in, four-out" policy. Accordingly, the Court's analysis situated migrants within a fictional world in which they were presumed to

Irshad, supra note 48 at para 133.

2011 FCA 213, [2013] 1 FCR 374 [Toussaint].

Ibid at para 99, citing Corbiere v Canada (Minister of Indian and Northern Affairs), [1999] 2 SCR 203 at para 13 .

Toussaint, ibid.

Ibid at para 72 . 
exercise unencumbered choice. Undocumented migrants were viewed as illegal rather than illegalized, and their precariousness was considered purely a result of their failure to make the proper decisions during their migratory process. This single-minded focus on "choice," as Sheila McIntyre observes in the Charter equality rights context, "individuates a collective and systemic problem and operates much as crude forms of stereotyping do, by making difference — i.e., individual inequality — an individual or group deficit, reasonably stigmatized or subject to moral blame." ${ }^{, 56}$

These legal precedents are unfortunate. Not only do they add to the hurdles that precarious status migrants must cross in the future when seeking to assert their right to health care in Canada, but they also legitimize a version of the anti-migrant narrative that portrays migrants who are excluded from public health care as rightly undeserving. Conveniently disappeared from the judicial discussion is the policymakers' deliberate efforts, on the one hand, to restrict certain migrants' access to permanent residency and force them to stay in the country by perpetually resorting to temporary or irregular immigration channels, and, on the other hand, use migrants' less-than-full status as justification for their health care exclusion. Such resistance to probe into the interworking between the immigration and the health care systems insulates migrant health care retrenchment from fulsome scrutiny, and renders the Canadian judiciary complicit in the government's neo-liberal agenda.

\section{B. ImPEDiments to Health CARE ACCESS}

Even for the precarious status migrants that are afforded health care coverage in Canada, their ability to convert this legal entitlement into de facto access may be hampered by their insecure presence in the country. To be sure, studies have shown that newcomers to Canada as a group, and not just those without permanent resident status, experience considerably greater difficulties in obtaining health care services than their native-born counterparts do. ${ }^{57}$ Factors that contribute to this disparity include, inter alia, the absence or geographical inaccessibility of culturally appropriate care, language barriers, migrants' unfamiliarity with the Canadian health care system or unawareness of the services available, and the worry that service utilization would jeopardize the outcome of one's immigration or refugee applications. ${ }^{58}$ However, beyond these general barriers, precarious status migrants encounter additional challenges with health care access that uniquely stem from the conditional and uncertain nature of their legal standing. By way of illustration, I will now turn my attention to the problematic health care access that seasonal agricultural migrants face in Canada.

56 Sheila McIntyre, "The Equality Jurisprudence of the McLachlin Court: Back to the 70s" in Sanda Rodgers \& Sheila McIntyre, eds, The Supreme Court of Canada and Social Justice: Commitment, Retrenchment or Retreat (Markham: LexisNexis Canada, 2010) 129 at 177.

57 See e.g. Claudia Sanmartin \& Nancy Ross, "Experiencing Difficulties Accessing First-Contact Health Services in Canada" (2006) 1:2 Healthcare Policy 103.

58 See e.g. Anita J Gagnon, "The Responsiveness of the Canadian Health Care Systems Towards Newcomers" in Pierre-Gerlier Forest, Gregory P Marchildon \& Tom McIntosh, eds, Changing Health Care in Canada: Romanow Papers, Vol. 2 (Toronto: University of Toronto Press, 2004) 349 at 356 57; Jennifer Asanin \& Kathi Wilson, “I Spent Nine Years Looking for a Doctor': Exploring Access to Health Care Among Immigrants in Mississauga, Ontario, Canada" (2008) 66:6 Social Science \& Medicine 1271. 
The vast majority of migrants that come to Canada through the Seasonal Agricultural Worker Program (SAWP) are employed in Ontario, Quebec, British Columbia, and Alberta. ${ }^{59}$ Whereas all migrant farm workers in Ontario and Quebec are furnished with public health care coverage, those in British Columbia and Alberta are only entitled to public health care benefits if they possess a work permit that is for longer than six months. ${ }^{60} \mathrm{SAWP}$ participants in British Columbia must also undergo a three-month waiting period before their health care eligibility takes effect. ${ }^{61}$ Irrespective of these differences, health care entitlement of seasonal agricultural migrants in Canada has been found to be largely illusory. Research indicates that SAWP participants usually must rely on their employers to get registered with the provincial health insurance plans, to obtain their health care cards (as some employers would hold onto the cards for "safekeeping"), and to arrange transportation to health care providers. ${ }^{62} \mathrm{Such}$ dependency on employers as facilitators of service utilization, from a logistical perspective, unnecessarily complicates migrants' timely access to health care. Moreover, it deters migrants from health care access for fear that doing so may vitiate employers' impression of them as "strong, healthy and resilient workers," 63 which could in turn cause them to be repatriated before their work permit expires or negatively affect their chances of being invited back for work next year. ${ }^{64}$ In Ontario alone, between 2001 and 2011, nearly 800 migrant farm workers had their employment terminated prematurely and were sent home against their will when they became ill, injured, or pregnant. ${ }^{65}$ Such a practice not only denies migrant farm workers proper access to health care that they are legally entitled to, but also gives other similarly situated migrants pause for thought before seeking medical attention.

In sum, as the Canadian immigration and health care laws and policies interweave, they deprive migrants of their security in life while simultaneously stymieing the full realization of migrants' right to health care. For medically uninsured migrants looking to change their fortune, their "temporarized" or illegalized status is used by decision-makers to excuse their health care disentitlement. And for precarious status migrants that are supposedly covered by public health insurance, their conditional presence in Canada ensures that such legal entitlements would for the most part remain theoretical as their actual service utilization is kept in check by the threat of removal from the country. If this status quo persists, the future arguably does not bode well for the right to health care of the growing number of precariousstatus migrants.

Michael Pysklywec et al, "Doctors Within Borders: Meeting the Health Care Needs of Migrant Farm Workers in Canada" (2011) 183:9 CMAJ 1039 at 1039.

Chen, "Extending Health Care Entitlement," supra note 36 at 111-12. For information on migrant workers' health care coverage in Alberta, see Alberta Health, "Temporary Residents and AHCIP," online: <http://www.health.alberta.ca/AHCIP/temporary-residents.html>.

Gerardo Otero \& Kerry Preibisch, Citizenship and Precarious Labour in Canadian Agriculture (Vancouver: Canadian Centre for Policy Alternatives, 2015) at 22, online: <www.policyalternatives.ca/ publications/reports/citizenship-and-precarious-labour-canadian-agriculture $>$.

Janet McLaughlin, Trouble in Our Fields: Health and Human Rights Among Mexican and Caribbean Migrant Farm Workers in Canada (PhD Thesis, University of Toronto Department of Anthropology, 2009) [unpublished] at 430-33.

Ibid at 433.

Jenna L Hennebry \& Kerry Preibisch, “A Model for Managed Migration? Re-Examining Best Practices in Canada's Seasonal Agricultural Worker Program” (2012) 50:S1 Intl Migration e19 at e26, online: $<$ onlinelibrary.wiley.com/doi/10.1111/j.1468-2435.2009.00598.x/epdf>.

Aaron M Orkin et al, "Medical Repatriation of Migrant Farm Workers in Ontario: A Descriptive Analysis" (2014) 2:3 Can Medical Assoc J Open E192. 


\section{Suggestions for Legal AND Policy Reform}

In my view, the key to improving precarious status migrants' health care security in Canada lies in unmasking and contesting the legal and policy forces that contribute to migrants' precarious presence in the first place. Whatever the original intention might have been when it was first conceived, Canada's temporary migration scheme has now clearly evolved into a policy stratagem that allows the government to roll back the rights and freedoms of non-citizen ordinary residents for its own economic and political gains. As illustrated, the designation of migrants as temporary or irregular despite their lived realities not only compromises these individuals' exercise of the right to health care, but also legitimizes this rights violation and shields it from proper judicial scrutiny. Therefore, to truly fulfill migrants' right to health care, the operating philosophy of Canada's contemporary immigration system must be revamped. The purposive channelling of immigration through programs that are designed to amplify and exploit migrants' precariousness must be stopped, and all migrants that have established ordinary residence in the country must be provided a genuine pathway to acquire legal permanent status.

Admittedly, this prescription puts me somewhat at odds with a popular strand of migrant rights advocacy that insists on separating questions about migrants' entitlement within the country from concerns over migrants' treatment at the borders. Supporters of this bifurcation often take the position that migrants' access to timely and appropriate health care can be effected by legislative and policy changes within the health care field alone, without any reforms being made to the immigration system. ${ }^{66} \mathrm{~A}$ similar logic appears to undergird international legal instruments that aim at advancing migrants' human rights, with the International Convention on the Protection of the Rights of All Migrant Workers and Members of their Families being a perfect case in point. ${ }^{67}$ On the one hand, the Convention requires countries to treat migrant workers and citizens equally in relation to health service access. ${ }^{68}$ But on the other hand, it assures states that their right to control migrant workers' border entry will not be undermined by any of its provisions. ${ }^{69}$ The problem with this bifurcated approach, as I have sought to demonstrate in this article, is that it underappreciates how insecurity underlying migrants' residency can hinder the actualization of their right to health care. Any attempts to advance migrants' rights without adequately policing how sovereign states exercise their authority over immigration control will, to borrow the words of Laurie Berg, risk having the latter "[infiltrate] the domain of [precarious status] migrants' substantive protections in other areas of domestic law, thus effectively defeating their enforceability."70

Against the backdrop of this proposed immigration reform, the Canadian public health care system must strive to extend coverage to all migrants who are de facto ordinarily resident in the country, irrespective of their legal classifications. In the event that such policy change is stalled by legislative inertia, the Canadian judiciary must be ready to serve as a

\footnotetext{
66 See e.g. Andrew J Pollard \& Julian Savulescu, "Ethics in Practice: Eligibility of Overseas Visitors and People of Uncertain Residential Status for NHS Treatment" (2004) 329:7461 British Medical J 346. 18 December 1990, 2220 UNTS 3 (entered into forces 1 July 2003). Ibid, art 43(1)(e).

Ibid, art 79.

Laurie Berg, "At the Border and Between the Cracks: The Precarious Position of Irregular Migrant
} Workers Under International Human Rights Law” (2007) 8:1 Melbourne J Intl L 1 at 19. 
catalyst for reform by engaging in a "Charter dialogue" with the legislature. This means that when another opportunity arises for courts to consider the government's constitutional duty toward medically uninsured migrants, they must be ready to pierce the veil of immigration statuses and consider the discriminatory effect of health care disentitlement based on migrants' real life circumstances. And they must also recognize the legal and policy architecture that constrains migrants' decision-making, and hold the government to account for the role that it plays in engendering the plight of medically indigent migrants. To hold the judiciary to such expectations is not unreasonable. In fact, courts in some other countries have expressed the willingness to engage in these very lines of analysis.

In Larbi-Odam v. MEC for Education (North-West Province), for instance, the South African Constitutional Court was asked to assess whether a provincial regulation that prohibited non-citizen teachers from obtaining permanent employment contracts breached the anti-discrimination clause of the interim constitution. ${ }^{71}$ In answering the question affirmatively, the Court rejected a request from the government to find only a partial constitutional infringement insofar as the impugned regulation offended the rights of permanent foreign residents. The Court held that the exclusion of temporary foreign residents from tenured teaching positions was just as discriminatory, considering that all the temporary migrants in this case had been in South Africa for a prolonged period of time by way of renewing their immigration permits annually. ${ }^{72}$ In other words, by allowing itself to look beyond the legal categorization of individuals, the Court was able to lay bare the injustice of differential treatment of citizens, permanent residents and regularly returning temporary residents, whose residency in the country all shared a quality of endurance.

Likewise, in Plyler v. Doe, the US Supreme Court exhibited a certain degree of openness to confront a state government's inferior treatment of migrants that was motivated by considerations detached from migrants' lived realities. ${ }^{73}$ The case dealt with the constitutionality of a Texan law that disallowed the enrolment of undocumented migrant children in public schools. Ruling against the government, the Court reasoned that whereas "[p]ersuasive arguments support the view that a State may withhold its beneficence from those whose very presence within the United States is the product of their own unlawful conduct,"74 such claims "do not apply with the same force to classifications imposing disabilities on the minor children of such illegal entrants." 75 That is, as much as policymakers might have had valid reasons to distinguish undocumented migrants from their lawful counterparts, to generalize this distinction to undocumented migrant children was unjust according to the Court, because children usually had little control over their immigration status. While the Court's conception of migrants' illegalized status as primarily a matter of personal choice, as in Toussaint, was disappointing, the exception that the Court made with respect to migrant children illustrated just how fragile this rhetoric of choice could be when migrants' real life experiences were properly accounted. Thus, this decision ought to give the Canadian judiciary some food for thought when the issue concerning the mutability of immigration status returns for another deliberation.

[1997] ZACC 16, [1997] 12 BCLR 1655 (S Afr Const Ct).

Ibid at para 41 .

457 US 202 (1982).

Ibid at 219.

Ibid at 219-20 [emphasis in original]. 
As this foreign jurisprudence shows, when judicial inquiries are able to move past the abstract legal categorizations imposed on migrants and become alive to people's factual circumstances, court challenges can serve as an important vehicle for the expansion of migrants' entitlements, including health care. However, as I have noted, even when migrants are granted public health care coverage, their access to timely and appropriate services can still be difficult in practice. To remedy this, commentators have put forth a range of recommendations for health care reform, including more routine usage of interpreters, enhancement of clinical cultural competence, employment of ethnocultural liaisons to help migrants navigate the health care system, and development of readily accessible information on migrants' health care eligibility as well as services available, among others. ${ }^{76}$ These initiatives must also be complemented by measures to remove the unnecessary access barriers foisted upon migrants by those who exercise power over them. For example, pertinent rules must be put in place and vigorously enforced to prohibit employers from withholding migrant workers' health care cards or repatriating migrant workers for medical reasons absent their informed consent. Without such multi-pronged reform, the future of precarious status migrants' right to health care in Canada will likely be grim.

\section{CONCLUSION}

In an article titled "History and the Future of International Migration," Göran Rystad remarks that "[h]istory is the only key we have to understanding the present and to making at least tentative predictions concerning the future and regarding the possible effects of decisions and policies." ${ }^{, 77}$ In this article, I adopted a similar approach to examining the past and future trajectory of precarious status migrants' right to health care in Canada. I began with a description of the growing preference of the Canadian immigration system for temporary migration over permanent settlement. I next showed how this shift in immigration policy resulted in migrants' precarious presence, and how this insecurity in turn constrained migrants' ability to fully realize their right to health care as guaranteed in international law. I highlighted the complicity of the Canadian judiciary in limiting migrants' health care entitlement, and I observed that even when migrants were made eligible for public health care, their access thereto could still be thwarted by the conditionality associated with their legal status. Looking toward the future, I suggested that the seemingly unrelenting appetite of Canada's immigration system for temporary migrants will continue to exert downward pressure on migrants' right to health care. If we are to hope for a more positive future, the immigration control assemblage that destabilizes foreign residents' ordinary presence in the country must be unravelled. Migrant rights advocates must resist the temptation to separate concerns about migrants' health care entitlement and access from those about their border entry and exclusion. The two fields are intimately connected. So long as migrants' lives remain precarious, whatever gains that may be made on paper regarding their right to health care will prove to be more symbolic than real.

$76 \quad$ See e.g. Gagnon, supra note 58 at $366-68$

77 Göran Rystad, "History and the Future of International Migration" (1992) 26 Intl Migration Rev 1168 at $1168-69$. 
